\title{
HUBUNGAN KOMPETENSI PEDAGOGIK DENGAN KINERJA MENGAJAR GURU DI KECAMATAN JAPARA KABUPATEN KUNINGAN
}

\author{
Dedeh Rusminah ${ }^{1}$, Ajeng Rahayu Tresna Dewi ${ }^{2}$ \\ TK PGRI Al-Madani ${ }^{1}$ \\ Program Studi Pendidikan Anak Usia Dini, STKIP Muhammadiyah Kuningan ${ }^{2}$ \\ Email :dedehrusminah17@gmail.com¹, ajeng@upmk.ac.id ${ }^{2}$
}

\begin{abstract}
Abstrak
Penelitian ini bertujuan untuk memperoleh informasi tentang hubungan kompetensi pedagogi dengan kinerja mengajar guru PAUD di kecamatan japara kabupaten kuningan. Metode yang di gunakan adalah kuantitatif korelasional. Teknik pengumpulan data dalam penelitian ini menggunakan angket dan dokumentasi. Sampel dalam penelitian ini menggunakan sampling jenuh yaitu 23 guru TK. Analisis data dalam penelitian ini menggunakan uji korelasi Pearson. Hasil penelitian menunjukkan bahwa terdapat hubungan antara kompetensi pedagogik guru dengan kinerja mengajar guru tk di kecamatan japara kabupaten kuningan di buktikan dengan nilai sig 0,000 lebih kecil dari 0,05.kompetensi pedagogik guru di kecamatan japara kabupaten kuningan termasuk ke dalam kategori tinggi yaitu sebesar 56,52\% yaitu13guru dari total sampel 23 guru. Kinerja mengajar guru di kecamatan Japara kabupaten kuningan termasuk ke dalam kategori tinggi yaitu sebesar $52,17 \%$ yaitu 12 guru dari total sampel 23 .
\end{abstract}

kata kunci : kompetensi pedagogik dan kinerja mengajar guru.

\begin{abstract}
This study aims to obtain information about the relationship of pedagogical competence with the teaching performance of PAUD teachers in the district of japara kabupaten Kuningan. The method used is quantitative correlational. Data collection techniques in this study used questionnaires and documentation. The sample in this study used saturated sampling, namely 23 kindergarten teachers. Data analysis in this study used the Pearson correlation test. The results showed that there was a relationship between the pedagogic competence of the teacher and the teaching performance of the teacher in the district of Kuningan district japara proven by a value of 0,000 smaller than 0.05. 52\%, namely 13 teachers from 23 sampels. Teacher teaching performance in Japara sub-district, brass district is included in the high category of $52.17 \%$ namely 12 teachers from 23 samples.
\end{abstract}

keywords: pedagogic competence and teacher teaching performance.

(C) 2019 Dedeh Rusminah ${ }^{1}$, Ajeng Rahayu Tresna Dewi ${ }^{2}$ Under the license CC BY-SA 4.0

http://jurnal.upmk.ac.id/index.php/pelitapaud 


\section{PENDAHULUAN}

Pendidikan anak usia dini (PAUD) diselenggarakan dengan tujuan untuk memfasilitasi pertumbuhan dan perkembangan anak secara menyeluruh atau menekankan pada pengembangan seluruh aspek kepribadian anak. Oleh karena itu, PAUD memberi kesempatan pada anak untuk mengembangkan kepribadian dan potensi secara maksimal. Sesuai dengan keunikan dan pertumbuhan anak usia dini, penyelenggaraan PAUD disesuaikan dengan tahap-tahap perkembangan yang dilalui oleh anak. Pendidikan pada anak usia dini pada dasarnya meliputi seluruh upaya dan tindakan yang dilakukan oleh pendidik dan orang tua dalam proses perawatan, pengasuhan dan pendidikan pada anak dengan menciptakan aura dan lingkungan dimana anak dapat mengeksplorasi pengalaman yang memberikan kesempatan kepadanya untuk mengetahui dan memahami pengalaman belajar yang diperolehnya dari lingkungan melalui cara mengamati meniru dan bereksperiman yang berlangsung secara berulang ulang dan melibatkan seluruh potensi dan kecerdasan anak.

Anak melewati berbagai tahap perkembangan kepribadian, maka lingkungan yang diupayakan oleh pendidik dan orang tualah yang dapat memberikan kesempatan pada anak untuk mengeksplorasi berbagai pengalaman dengan berbagai suasana..Dalam UU No. 20 Tahun 2003 tentang Sistem Pendidikan Nasional disebutkan bahwa guru PAUD harus memiliki kompetensi pendidik atau lembaga Pendidikan Anak Usia Dini (PAUD) memiliki kualifikasi akademik sekurangkurangnya Diploma Empat (D-IV) atau sarjana (S-1) dibidang Pendidikan Anak Usia Dini (S-I/ D-IV PG-PAUD) atau kependidikan lain, psikologi dan memiliki sertifikasi profesi guru PAUD atau sekurangkurangnya telah mendapatkan pelatihan pendidikan anak usia dini.

Peningkatan kualifikasi sumber daya manusia itu relevan dengan tuntutan peningkatan mutu kependidikan pada umumnya dan PAUD pada khususnya yang secara rasional mendahului pendidikan pada jenjang sekolah dasar dan selanjutnya. Diharapkan guru mampu menjangkau pendalaman secara komprehensif mengenai kajian tentang perkembangan peserta didik anak usia dini yang mendasari seluruh praktikkependidikan anak usia dini. Hal ini perlu disadari 
sepenuhnya mengingat PAUD selalu mengacu sepenuhnya pada perkembangan peserta didik dengan segenap dimensinya. Pendalaman seperti ini akan lebih mungkin dipenuhi oleh program pendidikan guru PAUD pada tingkat Perguruan Tinggi. Disamping itu, program pendidikan pada jenjang yang lebih tinggi akan mampu menyelenggarakan penelitian di bidang pendidikan anak usia dini pada umumnya. Khususnya kePAUDan, dimana hal ini masih sangat minim di Indonesia.

\section{Guru PAUD bertugas} mengembangkan dimensi-dimensi perkembangan secara optimal. Dalam usaha peningkatan dan pembelajaran yang dapat dilakukan guru sebagai agen perubahan melalui kegiatan pembenahan kinerja guru dengan wadah pembinaan kelembagaan, pembinaan kelembagaan kurikulum, ketenagaan, sarana dan prasarana serta perubahan lainnya. Pada kenyataannya menunjukkan bahwa tingkat kemajuan sekolah sangat ditentukan oleh sejauh mana tingkat kinerja guru disekolah. Bahwa didorong oleh kedasaran untuk berperan serta dalam pembangunan nasional terutama dalam meningkatkan kualitas dan kesejahteraan anak khususnya dalam rangka menunjukkan kebijakan dan strategi pengasuhan, perawatan, pendidikan anak usia dini dengan adanya peran dari guru Pendidikan Anak Usian Dini (PAUD) tentang pentingnya Pendidikan Anak Usia Dini (PAUD) ini didasari rasa kepedulian dan rasa tanggung jawab terhadap sebagai pendidik yang berperan ingin memajukan melalui menyekolahkan anak sejak dini.Untuk mencapai keberhasilan pendidikan dan meningkatkan mutu pendidikan, guru harus memiliki kompetensi yang memadai. Kompetensi merupakan kemampuan untuk melaksanakan sesuatu yang diperoleh melalui pendidikan dan latihan.

Kompetensi merupakan kemampuan yang harus dimiliki seseorang baik pengetahuan, keterampilan, maupun nilai dan sikap untuk melakukan suatu pekerjaan Adapun empat kompetensi dasar yang harus dimiliki oleh seorang guru diantaranya kompetensi pedagogik, kompetensi kepribadian, kompetensi sosial, danKompetensi professional (Priatna, 2013: 5). Hal tersebut berimplikasi bahwa seorang guru harus mampu menguasai teori belajar dan prinsip-prinsip belajar, karena siswa memiliki karakter, sifat, dan interest yang berbeda. Berkenaan dengan 
pelaksanaan kurikulum, seorang guru harus mampu mengembangkan kurikulum tingkat satuan pendidikan masing-masing dan disesuaikan dengan kebutuhan lokal. Guru harus mampu mengoptimalkan potensi peserta didik untuk mengaktualisasikan kemampuannya di kelas, dan harus mampu melakukan kegiatan penilaian terhadap kegiatan pembelajaran yang telah dilakukan.

Kinerja guru bagi sekolah merupakan suatu hal yang penting, karena dapat menunjukkan adanya keberhasilan sekolah dalam mencapai tujuan dan menunjukkan seberapa jauh hal-hal apa yang telah diperbuat guru agar dapat memenuhi dan memuaskan masyarakat sebagai penguna jasa. Kinerja guru merupakan salah satu fakta penentu keberhasilan setiap upaya pendidikan. Itulah sebabnya, setiap adanya motivasi pendidikan khususnya dalam peningkatan sumber daya manusia yang dihasilkan guru menjadi sangat penting. Memang banyak usaha pembaharuan yang telah dilakukan seperti kurikulum, metode, pembinaan dan penyuluhan, akan tetapi itu semua belum bisa meningkatkan kinerja guru secara maksimal, Purwanto (2010:145) dengan demikian kinerja gurudi sekolah sangat menentukan keberhasilan baik untuk sekolah itu sendiri maupun bagi anak didik.

Kinerja mengajar guru adalah prestasi yang diperlihatkan dalam bentuk perilaku. Kinerja adalah hasil kerja secara kualitas dan kuantitas yang dicapai seseorang dalam melaksanakan tugasnya sesuai dengan tanggung jawab yang diberikan kepadanya (Wahyudi, 2012:128). Kinerja guru merupakan prestasi guru sebagai hasil dorongan yang diperlihatkan dalam bentuk perilaku. Selain itu kinerja juga dapat diartikan sebagai suatu hasil usaha seseorang yang dicapai dengan adanya kemampuan dan perbuatan dalam situasi tertentu.

Melalui kinerja ini tentunya guru harus menjadi teladan baik menjadi roll model atau panutan untuk anak didik dengan memiliki empat kompetensi diantaranya kompetensi pedagogik, kompetensi kepribadian, kompetensi profesional dan kompetensi sosial. Oleh karena itu dalam penelitian ini peneliti hanya membatasi pentingnya kompetensi pedagogik menjadi salah satu keberhasilan guru dalam mengelola dan memberikan pembelajaran yang dapat diterima oleh anak.

Berdasarkan hasil wawancara peneliti dengan guru dan kepala TK di 
kecamatan japara kabupaten kuningan bahwa beberapa guru masih mengalami kesulitan dalam merancang kegiatan awal anak,beberapa guru kesulitan dalam merancang kegiatan awal anak, beberapa guru kesulitan menguasai materi pelajaran. Artinya, dalam penyampaikan pembelajaran guru tidak memahami materi yang akan disampaikan, beberapa guru kesulitan dalam menerapkan pendekatan pembelajaran yang kurang efektif. Artinya dalam pembelajaran guru hanya memakai satu strategi. Sedangkan ada banyak strategi pembelajaran yang lainnya, beberapa guru kesulitan memanfaatan sumber belajar/media dalam pembelajaran. Artinya, disini guru hanya menjelaskan atau bercerita tanpa menggunakan media,masih ada beberapa ketidaksesuainya rancangan pembelajaran yang telah dibuat dengan pembelajaran yang dilakukan. Contohnya, guru membuat RPPH tetapi dalam pelaksanaan pembelajaran, tidak sesuai dengan RPPH yang sudah disiapkan. Misalnya: pada kegiatan inti ada beberapa kegiatan diantaranya mengamati, menanya, mengumpulkan informasi, menalar, dan mengkomunikasikan. Pada saat pembelajaran di kelas, salah satu dari kegiatan inti ini tidak dilakukan oleh guru,beberapa guru kesulitan dalam melakukan evaluasi dan penilian dan hanya melakukan penilaian diakhir semester saja.

Berdasarkan hal diatas, untuk mengingat bahwa perancangan dan pelaksanaan serta penerapan praktik mengajar merupakan bagian dari kompetensi pedagogik, dan kompetensi pedagogik sangatlah penting untuk penyelenggaraan praktik kependidikan anak, maka peneliti tertarik untuk meneliti dan memperoleh informasi tentang hubungan kompetensi pedagogik dengan kinerja mengajar guru TK. Hal tersebut menjadi dasarpeneliti untuk melakukan penelitian terkait "Hubungan Kompetensi Pedagogik Dengan Kinerja Mengajar Guru di Kecamatan Japara Kabupaten Kuningan”.

\section{METODE PENELITIAN}

Metode Penelitian dalam penelitian ini penulis menggunakan metode kuantitatif korelasional. Pada metode ini dapat terlihat hubungan antar variabel. Pada umumnya penelitian kuantitatif dapat dilaksanakan juga sebagai penelitian deskriptif. Metode kuantitatif korelasional adalah suatu proses 
menemukan pengetahuan yang menggunakan data berupa angka sebagai alat menemukan keterangan mengenai apa yang ingin kita ketahui dengan maksud untuk mencari hubungan antara variabel independen (X) dengan variabel dependen (Y).

\section{Jenis Penelitian}

Penelitian ini mengunakan metode kuantitatif korelasional.

\section{Waktu dan tempat penelitian}

Penelitian ini dilakukan pada bulan Mei 2019. Bertempat di kecamatan Japara Kabupaten Kuningan

\section{Subjek Penelitin}

\section{Populasi}

Sugiyono (2012: 80) menyatakan bahwa populasi adalah wilayah generalisasi yang terdiri atas: obyek/subyek yang mempunyai kualitas atau karakteristik tertentu yang ditetapkan oleh peneliti untuk dipelajari dan kemudian ditarik kesimpulannya. Populasi dalam penelitian ini adalah seluruh guru TK di Kecamatan Japara Kabupaten Kuningan dengan jumlah keseluruhan 23 orang guru.

\section{Sampel}

Dalam sebuah penelitian, teknik sampling merupakan bagian yang sangat penting, karena dengan adanya teknik sampling peneliti dapat dengan mudah menentukan sampel-sampel yang akan diteliti. Teknik sampling yang digunakan adalah SamplingJenuh, Kualifikasi pendidikan sampel adalah sarjana pendidikan PAUD dan seluruhnya adalaha guur perempuan denngan rentan usia 23-45 tahun.

\section{Instrumen Penelitian}

Instrumen penelitian merupakan alat bantu dalam suatu penelitian yang digunakan peneliti untuk memperoleh fakta-fakta terkait objek penelitian. Adapun instrumen yang digunakan dalam penelitian ini adalah angket. Instrumen tersebut diberikan kepada guru TK tentang kemampuan pedagogik dan kinerja mengajar yang dimiliki guru. Pengembangan instrumen ditempuh melalui beberapa tahap, yaitu: (1) menyusun indikator variabel penelitian, (2) menyusun kisikisi instrumen, (3) melakukan pengujian validitas dan reliabilitas instrumen.

\section{Teknik Pengumpulan Data}

Kualitas instrumen dan kualitas penngumpulan data merupakan hal utama yang mempengaruhi kualitas data hasil penelitian. Kualitas pengumpulan data berkenaan dengan ketepatan cara-cara yang digunakan untuk mengumpulkan data. Teknik 
pengumpulan data pada penelitian ini menggunakan angket/kuesioner dan dokumentasi.

\section{Teknik Analisis Data}

\section{Uji Instrumen}

Menurut Sugiyono (2013: 63) bahwa "Analisis data adalah proses mencari dan menyusun secara sistematis data yang diperoleh dari hasil wawancara, catatan lapangan, dan bahan-bahan lain, sehingga dapat mudah dipahami, dan temuannya dapat diinformasikan kepada orang lain”.

Uji normalitas data dalam penelitian ini digunakan untuk memenuhi prasyarat analisis parametrik dengan menguji normalitas data populasi. Uji normalitas tersebut menuntut suatu asumsi yang harus diuji, yaitu populasi dilakukan dengan menggunakan Kolmogrov Simirnov dengan bantuan SPSS 21.00 for windows.

Uji linieritas data dalam penelitian ini bertujuan untuk mengetahui apakah dua variabel mempunyai hubungan yang linier atau tidak secara signifikan. Uji linieritas dilakukan dengan pengujian pada SPSS 21.0 for windows dengan menggunakan test for linearity pada taraf signifikansi $(\mathrm{p}>0,05)$.

\section{Uji Hipotesis}

Teknik analisis data diarahkan pada pengujian hipotesis yang diajukan serta untuk menjawab rumusan masalah, pada penelitian ini menggunakan analisis korelasi. Analisis korelasi dengan menggunakan uji koefisien korelasi yang dimaksudkan untuk mengetahui derajat hubungan antara variabel $\mathrm{X}$ (Kompetensi Pedagogik) dengan variabel Y (Kinerja Mengajar Guru). Pengujian hipotesis ini menggunakan bantuan SPSS 21.00 for windows.

\section{Analisis Data Penelitian}

\section{Uji Normalitas}

Uji normalitas dilakukan untuk menguji asumsi bahwa distribusi data membentuk distribusi normal. Normalitas data dalam penelitian ini menggunakan

KolmogorovSmirnovdengan taraf signifikansi ( $\mathrm{p}>0,05)$, dengan bantuan SPSS 21.0 for Windows. Adapun dasar pengambilan keputusan dalam uji normalitas menggunakan pedoman sebagai berikut.

$$
\begin{aligned}
& \mathbf{H o}=\text { Data tidak berdistribusi normal } \\
& \mathbf{H a}=\text { Data berdistribusi normal }
\end{aligned}
$$

Berdasarkan hasil perhitungan yang merupakan hasil out put SPPS versi 21 tersebut, diketahui nilai signifikasi Asiymp.Sig (2-tailed) sebesar 0,637 lebih besar dari 0,05. Maka sesuai dengan pengambilan keputusan dalam uji normalitas kolomogorov- smirnov 
di atas, dapat disimpulkan bahwa data berdistribusi normal. Dengan demikian, asumsi atau persyaratan normalitas dalam model linearitas sudah terpenuhi. Dengan demikian maka populasi dalam penelitian ini berdistribusi normal.

\section{Uji Linearitas}

Uji linieritas data bertujuan untuk mengetahui apakah dua variabel mempunyai hubungan yang linier atau tidak secara signifikan. Uji linieritas dilakukan dengan pengujian pada SPSS 21.0 for windows dengan menggunakan test for linearity pada taraf signifikansi $(p>0,05)$. Adapun dasar pengambilan keputusan dalam uji linieritas menggunakan pedoman sebagai berikut.

1) Jika nilai sig. > 0,05, maka ada hubungan yang linear secara signifikan antara variabel $\mathrm{X}$ dan variabel Y.

2) Jika nilai sig. <0,05 maka tidak ada hubungan yang linear secara signifikan antara variabel $\mathrm{X}$ dan $\mathrm{Y}$.

\section{Hasil Uji Linearitas}

Berdasarkan tabel 4.8 diketahui nilai sig $=0,407$. Jelas bahwa sig > 0,05 . Berdasarkan hasil perhitungan tersebut dapat disimpulkan bahwa terdapat hubungan linier antara variabel
Kompetensi pedagogik guruTK (X) dan variabel kinerja guru TK (Y).

\section{Uji Hipotesis (Uji Korelasi Pearson)}

Setelah uji persyaratan analisis dilakukan maka selanjutnya menguji hipotesis yang didasarkan pada uji korelasi pearson.Uji korelasi pearson dalam penelitian ini digunakan untuk menguji kekuatan dan arah hubungan linear antara variabel $\mathrm{X}$ dan $\mathrm{Y}$. Dua variabel dikatakan berkorelasi apabila perubahan salah satu variabel disertai dengan perubahan variabel lainnya, baik dalam arah yang sama ataupun sebaliknya. Adapun ketentuan pengujian ini adalah sebagai berikut:

Apabila nilai sig. $<0,05$ maka ada hubungan yang signifikan, apabila sig > 0,05 maka tidak ada hubungan yang signifikan. Untuk melihat arah hubungan apabila tanda koefisien (-) berarti apabila variabel $\mathrm{X}$ tinggi maka variabel $\mathrm{Y}$ rendah, apabila tanda koefisiean (+) berarti apabila variabel $\mathrm{X}$ tinggi maka variabel $\mathrm{Y}$ juga tinggi. Berdasarkan hasil statistik, diketahui nilai sig. Adalah $0,000<0,05$, sesuai dengan ketentuan maka kesimpulan penelitian ini adalah adanya hubungan antara variabel $\mathrm{X}$ (kompetensi kinerja guru TK) dan variabel Y (kinerja guru TK) di Kecamatan Japara Kabupaten Kuningan. Selain itu, diketahui pula 
tanda koefisien data tersebut adalah (+) maka dapat ditarik kesimpulan bahwa adanya hubungan yang positif antar kedua variabel atau bisa dijelaskan apabila kompetensi kpedagogik guru TK tinggi maka kinerja guru TK tersebut juga tinggi.

\section{HASIL PENELITIAN DAN PEMBAHASAN}

Setelah peneliti melakukan pengolahan data, diperoleh gambaran tentang Kompetensi Pedagogik Guru TK dan Kinerja Guru TK di Kecamatan Japara Kabupaten Kuningan sebagai berikut.

\section{Gambaran Kompetensi Pedagogik \\ Guru TK di Kecamatan Japara} Kabupaten Kuningan (variabel X)

Berdasarkan hasil analisis deskripsi diperoleh gambaran Kompetensi Pedagogik Guru TK di Kecamatan Japara Kabupaten kuningan (variabel $\mathrm{X}$ ) mendapat skor tertinggi sebesar 60 dan skor tebanyak adalah skor dengan kategori tinggi sebesar $56,52 \%$.

Gambaran Kinerja Guru TK di Kecamatan Japara Kabupaten Kuningan (variabel Y)

Berdasarkan hasil analisis deskripsi diperoleh gambaran Kinerja
Guru TK (variabel Y) menurut presepsi kepala sekolah TK di Kecamatan Japara Kabupaten kuningan mendapat skor tertinggi sebesar 75 dan skor tertinggi adalah termasuk kategori tinggi sebesar $52,7 \%$.

\section{SIMPULAN}

Berdasarkan hasil penelitian dan pembahasan Hubungan Kompetensi Pedagogik Guru dan Kinerja Guru TK di Kecamatan Japara Kabupaten Kuningan, maka peneliti dapat menarik kesimpulan kompetensi pedagogik guru TK di Kecamatan Japara Kabupaten Kuningan termasuk dalam kategori tinggi sebesar 56,52\%.

Kinerja guru TK di Kecamatan Japara Kabupaten Kuningan termasuk dalam kategori tinggi sebesar 52,17\%. Terdapat hubungan yang signifikan antara kompetensi pedagogik guru dan kinerja guru TK di Kecamatan Japara Kabupaten Kuningan bedasarkan hasil analisis mencari hubungan antara kompetensi pedagogik dan kinerja guru TK yang dilihat dari hasil uji korelasi pearson diperoleh nilai sig yaitu 0,000 yang lebih kecil dari 0,05, hal tersebut menunjukan hasil bahwa terdapat hubungan yang signifikan antara kompetensi pedagogik guru TK dan kinerja guru TK di Kecamatan Japara 
Kabupaten Kuningan. Selain itu, diketahui pula tanda koefisien data tersebut adalah (+) maka dapat ditarik kesimpulan bahwa adanya hubungan yang positif antar kedua variabel atau bisa dijelaskan apabila kompetensi pedagogik guru TK tinggi maka kinerja guru TK tersebut juga tinggi. Hal tersebut menunjukan terdapat hubungan positif antara Kompetensi Pedagogik Guru TK dengan Kinerja Guru TK di Kecamatan Japara Kabupaten Kuningan.

\section{DAFTAR PUSTAKA}

Priatna, Nanang dan Sukamto, Tito. (2013). Pengembangan Profesi Guru. Bandung: PT Remaja Posdakarya.

Sugiyono. (2012). Metode Penelitian Pendidikan. Bandung: Alfabeta.

Sugiyono. (2013). Metode Penelitian Pendidikan. Bandung: Alfabeta.

Wahyudi, imam. (2012). Pengebangan Pendidikan Strategi Inovatif dan kreatif Dalam Pengelolaan Pendidikan Secara Komprehensip. Jakarta: PT Prestasi Pustaka Raya.

Afiatin, T., \& Andayani, B. (2016). Pelatihan Keterampilan Mendongeng untuk Keluarga Nelayan. Jurnal Pengabdian Kepada Masyarakat (Indonesian Journal of Community Engagement), 2(1), 53-65.
Dickinson, David K., and Catherine E. Snow. "Interrelationships among prereading and oral language skills in kindergartners from two social classes." Early Childhood Research Quarterly 2.1 (1987): 1-25.

Ika Budi M. (2016). Peran Pendidik PAUD dalam Membangun Karakter Anak. Jurnal Pendidikan Anak, 5.(1), 747-752 